\title{
Parametric optimization of autoclave curing for energy cost reduction of fiber cement panels
}

\author{
Rustem Mukhametrakhimov ${ }^{1,}{ }^{*}$, and Liliya Lukmanova ${ }^{1}$ \\ ${ }^{1}$ Kazan State University of Architecture and Engineering, Zelenaya str., 1, Kazan, 420043, Russia
}

\begin{abstract}
The results of experimental research on parametric optimization of autoclave curing for energy cost reduction of fiber cement panels are presented. Relation between the flexural strength of fiber cement panels and heating rate, the time of isothermal aging, the cooling rate of the autoclave has been established by the three-factor design of the second order.
\end{abstract}

\section{Introduction}

Much has been written about the autoclave processes of different materials (P.I. Bozhenov, P.P. Budnikov, A.V. Volzhensky, P.G. Komokhov, O.P. Mchedlov-Petrosyan, etc.).

A.V. Volzhensky [1] developed principal points of the theory of steaming lime-siliceous materials, which are acceptable for autoclave curing of all materials.

The first stage includes the period of steaming, which starts from the moment while the steam is entering into the autoclave and ends when the temperature of the coolant and the work materials is identical.

The second stage is characterized by a constant temperature and pressure in the autoclave. Creation of cementing particles and hardening of concrete products, which are caused by physical and mechanical processes, are more observable.

The third stage starts when the steaming is stopped, and it includes the cooling time of the products in the autoclave until they will be removed.

Considerable thermal stresses arise in steamed product due to the various temperatures of it and the steam at the first stage of treatment. The more evident they are, the higher rate of temperature elevation is. Thermal stress could be the cause both of disruption of the material structure, their strength loss and complete destruction.

Curing time of the raw mixture before autoclaving on which physical and mechanical processes of hydration of the binder and the formation of the structure occur, have strong effect on the qualitative adjectives of steam-cured materials. There is an optimal aging time for each composition of raw mix before their autoclave treatment [2].

Fiber cement products are subjected to steaming at a temperature of $55-60{ }^{\circ} \mathrm{C}$ under the regime $3+6+3$ hours after pressing during the manufacturing process. At the same time, the samples gain initial strength, which allows them to be removed from the moulds without defects and prepared for autoclaving.

\footnotetext{
* Corresponding author: muhametrahimov@mail.ru
} 
We can consider that additional curing time before autoclaving of the fiber cement panel (FCP) binder is not required and rate of temperature elevation can be increased because physical and mechanical processes of hydration and the formation of the structure occur while steaming.

Processes, that lead to the formation of a monolith, have full development at the second stage. The process determining the rate of formation of cementing particles should be considered as a transition of amorphous silica to the solution and the formation of polysilicic acid. Therefore, the higher the activity of mineral components is, the faster the growth of substances is.

The strength of the hardened binder depends on the degree of hydration, content of substances, their qualitative characteristics, degree of dispersion, type of binder, conditions and duration of the hardening [3].

The thickness of the steamed products influences on the duration of isothermic aging. In the case of various concrete [4] there is evident to suggest that as thickness of steamed products of all types of concrete increases, the duration of isothermic aging increases.

The aforementioned allows us to assume that thin FCP (thickness 8-10 mm), which contain a thin-milled high-reactive mineral additive and a fine-grained mineral filler, would require less duration of isothermic aging to achieve full hydration.

At the third stage of steaming the temperature and pressure decrease in the autoclave when the steam supply is stopped. The temperature of the pore water of the material decreases followed by subsequent evaporation.

Intensive water run and steam, which can significantly disrupt the structure of the cementing materials and reduce the strength of the products when quickly pressure relief is occured, can be arised in the sample when the autoclave is cooled by vapor relief.

A feature of the third stage of steaming is the drying out of products and cementing substances, which affects on the properties of material and, first of all, strength.

Differentiated approach to the choice of the autoclave curing regime at all stages is required for materials and products of different chemical and mineralogical formulations [5]. In several earlier studies [6, 7], formulations of fiber cement panels have been developed and the efficiency of their modification by organosilicon compounds for improving water resistance has been shown [8].

\section{Materials and Methods}

The following materials were used in the research process:

a) binder:

- portland cement PTS500-D0-H GOST 10178-85 OAO Volskcement.

b) aggregate:

- ground quartz sand of Kama deposit with specific surface area $310 \mathrm{~kg} / \mathrm{m} 2$.

c) fibers:

- cellulose fibres NSK STO 00279189-2-2007 OAO Solombalski TSBK.

d) modifying additives:

- polyacrylamide Besfloc K4045 TS 6-01-1049-92 KOLON LIFE SCIENCE, INC. (ion charge - anionic, ion charge high, viscosity of $0.2 \%$ solution at $25^{\circ} \mathrm{C}-550 \mathrm{cps}, \mathrm{pH} 0.1 \%$ solution $-6.9 \%$ );

- polyphenylethoxysiloxane FES-50 TS 2257-441-05763441-2005 OAO Khimprom Novocheboksarsk;

- kaolin TS 5729-016-48174985-2003 OOO NPP Promyshlennyye mineraly, Togliatti.

e) water:

- piped drinking water GOST 23732. 
Samples were produced by a wet method for producing fiber cement products in the following sequence. Cellulose pulps were refined separately on a Valley beater until a Shopper-Riegler degree of 30-35 was reached, then fibers were mixed with quartz sand, which was previously milled until a degree of grinding of $310 \mathrm{~m} 2 / \mathrm{kg}$ was reached, after that heat-treated kaolin, which was previously milled until a degree of grinding of $1300 \mathrm{~m} 2 / \mathrm{kg}$ was reached, portland cement, polyacrylamide, polyphenylethoxysiloxane and water were added. Further, the samples were formed by filtering the water from the fiber cement mixture until necessary seal was reached. Thereafter, the samples were put into defined shape and dimensions, after that the products (panels) were pressed and heat-and-moisture treated in the steam curing chamber. The final hardening of the products was carried out in an autoclave.

Thermoregulator TPM-200 OVEN was used to control the modes of autoclave curing regimes. Bending strength of samples (R), water absorption (W) and frost resistance (F) after autoclaving were determined in accordance with GOST 8747-88 [4].

Measurement of shrinkage deformations was carried out on samples with size 220x100x8mm, using an automatic logger shrinkage deformation Autograph. The device is equipped with sensors of linear deformation, temperature and humidity of the environment.

The air resistance of FCP was determined by a known technique based on determining the strength of the sample after alternating moistening and drying cycles. Air resistance coefficient equal to the ratio of the bending strength of the FCP, which was subjected to humidification and drying, to the check sample was adopted as an evaluation criterion.

\section{Results}

We performed experimental studies on the effect of the rate of temperature elevation and pressure until required value was achieved, the duration of isothermic aging at the maximum temperature, and the conditions for the descent of pressure from maximum to atmospheric on the physico-mechanical properties of the FCP to confirm our assumptions and to determine the optimal parameters for autoclave curing of modified FCP.

Optimization of the autoclave curing regime of the fiber cement mixture [9] based on the modified mixed binder [10] was carried out by a three-factor design of the second order on the hypercube. Rate of temperature elevation $\left(\mathrm{X}_{1}\right)\left(87.5-116.7{ }^{\circ} \mathrm{C} / \mathrm{h}\right)$; duration of isothermic aging $\left(\mathrm{X}_{2}\right)(4-8$ hours $)$; rate of cooling $\left(\mathrm{X}_{3}\right)\left(87.5-116.7^{\circ} \mathrm{C} / \mathrm{h}\right)$ were determined as initial independent variables.

Variation levels of independent variables are shown in the Table 1.

Table 1. Variation levels of independent variables

\begin{tabular}{|c|c|c|c|c|}
\hline \multirow{2}{*}{ Factor } & \multirow{2}{*}{ Name of factor } & \multicolumn{3}{|c|}{ Variation levels } \\
\hline & & $-\mathrm{I}$ & 0 & $+\mathrm{I}$ \\
\hline $\mathrm{X}_{1}$ & $\begin{array}{c}\text { rate of temperature } \\
\text { elevation }\end{array}$ & 116.7 & 87.5 & 116.7 \\
\hline $\mathrm{X}_{2}$ & $\begin{array}{c}\text { duration of } \\
\text { isothermic aging }\end{array}$ & 4 & 6 & 8 \\
\hline$X_{3}$ & rate of cooling & 11.7 & 87.5 & 58.3 \\
\hline
\end{tabular}

Bending strength of autoclaved fiber cement panels (FCP) was chosen as a response. Interpretation of the results of mathematical planning made it possible to obtain the following mathematical dependence:

$$
\begin{aligned}
& R=-79.796+0.6035 X_{1}+11.33 X_{2}+0.81 X_{3}+0.00489 X_{1} X_{2}+0.00089 X_{1} X_{3}-0.0236 X_{2} X_{3}- \\
& 0.0037 X_{1}^{2}-0.68529 X_{2}^{2}-0.0036 X_{3}^{2}
\end{aligned}
$$


Estimation of their statistical significance with a table value (Fisher's variance ratio) was made to determine the adequacy of the regression equations obtained. The results are shown in the Table 2.

Table 2. Statistical estimation of regression equations obtained

\begin{tabular}{|c|c|c|}
\hline \multirow{2}{*}{$\begin{array}{c}\text { № of regression } \\
\text { equation }\end{array}$} & \multicolumn{2}{|c|}{ Fisher's variance ratio } \\
\cline { 2 - 3 } & Table value & Target value \\
\hline 1 & 5.05 & 4.36 \\
\hline
\end{tabular}

Fig. 1-3 show a graphical interpretation of the results of interpretation of the results of mathematical model (1). As follows from the regression equation (1) and the data which is shown in Fig. 1-3, as duration of isothermic aging increases and rate of cooling decreases, the strength of the FCP increases. The reduction of autoclave curing regime, namely, a cooperative reduction of the duration of isothermic aging to 5 hours and an increase in the rate of temperature elevation in the autoclave to $87.5^{\circ} \mathrm{C} / \mathrm{h}$, does not significantly affect on the physical and mechanical properties of the FCP. Further reduction of the duration of isothermic aging and increase in the rate of temperature elevation leads to strength reduction of FCP.

Strength reduction of FCP with increase in rate of cooling is explained in terms of occurring of considerable thermal stresses, intensive water run and steam significantly disrupt the structure of the cementing materials when quickly pressure relief.

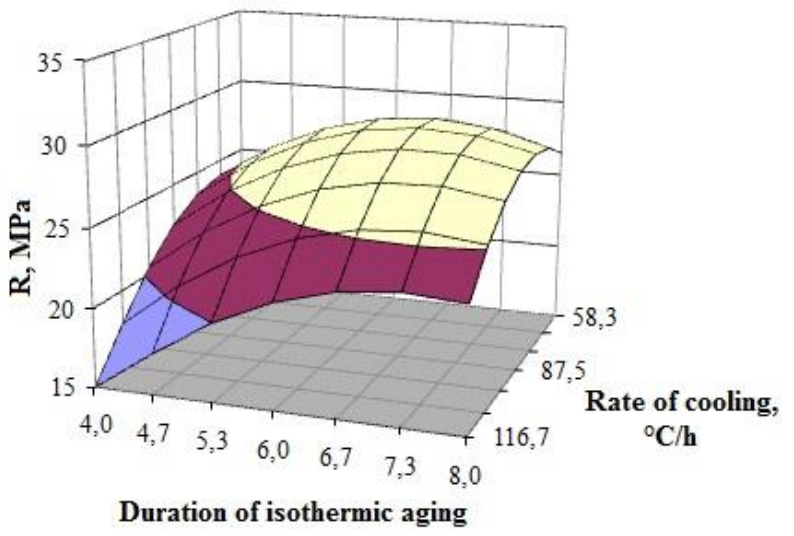

Fig. 1. The effect of the autoclave curing regime on the bending strength of FCP: $\mathrm{X}_{1}$ - const.

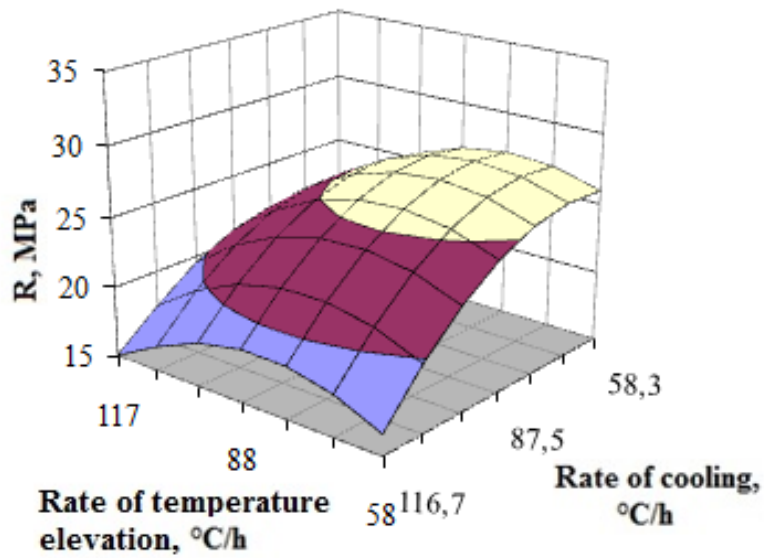

Fig. 2. The effect of the autoclave curing regime on the bending strength of FCP: $\mathrm{X}_{2}$ - const. 


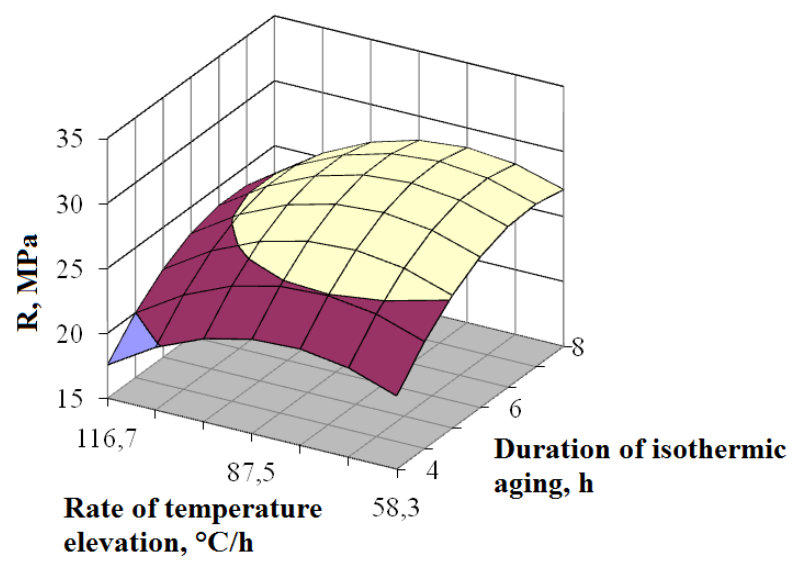

Fig. 3. The effect of the autoclave curing regime on the bending strength of FCP: $\mathrm{X}_{3}$ - const.

Discussion of the present findings made it possible to conclude that an increase in the rate of temperature elevation from 58 to $88{ }^{\circ} \mathrm{C} / \mathrm{h}$ does not have a significant effect on the strength characteristics of the FCP.

Increase in the rate of temperature elevation above $88{ }^{\circ} \mathrm{C} / \mathrm{h}$ and increase in the rate of cooling above $88^{\circ} \mathrm{C} / \mathrm{h}$ leads to a noticeable strength reduction of FCP.

FCP samples obtained by optimal autoclave curing regime were subjected to water absorption test, frost resistance test, shrinkage/swelling deformations test, air resistance test, water resistance and thermal conductivity tests. It has been established that shortening the duration of autoclave curing does not produce a decrease in performance characteristics of FCP.

\section{Conclusions}

- It has been established that the optimal parameters of autoclaved curing of the FCP with increased sustainability are: rate of temperature elevation is $88{ }^{\circ} \mathrm{C} / \mathrm{h}$, duration of isothermic aging at $\mathrm{t}=175^{\circ} \mathrm{C}$ and $\mathrm{P}=1 \mathrm{MPa}$ is 5 hours, the rate cooling is $88{ }^{\circ} \mathrm{C} / \mathrm{h}$. Parametric optimization of autoclave curing has reduced its duration by 4 hours.

- FCP with the following specific characteristics were obtained: bending strength -27.5 $\mathrm{MPa}$, thermal conductivity $0.22 \mathrm{~W} / \mathrm{m}{ }^{\circ} \mathrm{C}$, shrinkage $0.2 \mathrm{~mm} / \mathrm{m}$, frost resistance 250 cycles, air resistance 300 cycles, shock viscosity $-2.5 \mathrm{~kJ} / \mathrm{m}^{2}$, water absorption $-3 \%$, coefficient of water resistance -0.95 .

\section{References}

1. A.V. Volzhenskiy, Mineralnyye vyazhushchiye veshchestva (Stroyizdat, Moscow, 1986)

2. P.I. Bozhenov, Tekhnologiya avtoklavnykh materialov (Stroyizdat, Leningrad, 1978)

3. Kh.S. Vorobyev, Vyazhushchiye materialy dlya avtoklavnykh izdeliy (Stroyizdat, Moscow, 1972)

4. Y.V. Khomchenko, Povysheniye effektivnosti avtoklavnykh materialov na osnove modifikatsii vyazhushchego, (PhD Thesis, Belgorod, 2008) 
5. GOST 8747-88 (ST SEV5851-86) Asbestos-cement sheet products. Test methods, (Izdatelstvo standartov, Moscow, 1988)

6. R.Kh. Mukhametrakhimov, L.V. Lukmanova, Advances in Intelligent Systems and Computing, 692852 (2018)

7. V.S. Izotov, R.Kh. Mukhametrakhimov, L.S. Sabitov, Stroitel'nye Materialy, 520 (2011)

8. R.Kh. Mukhametrakhimov, L.V. Lukmanova, A.F. Khuzin, IOP Conference Series: Earth and Environmental Science, 90 (2017)

9. V.S. Izotov, R.Kh. Mukhametrakhimov, Patent RF 2486150, S 04 B 28/04, Fibrotsementnaya smes; Publication date: 27.06.13

10. V.S. Izotov, R.Kh. Mukhametrakhimov, Pat. RF 2500633, S04V 22/00, Organomineral'nyy modifikator dlya fibrotsementnykh kompozitsiy; Publication date: 10.12.2013 